\title{
Izhevsk in Revolt
}

\section{The "Third Force" in Power from August to November 1918}

\author{
Dimitrii Churakov
}

In the Russian Federation, an active search for historical precedents for the new structure of power has been ongoing ever since the abolition of the Soviet state. ${ }^{1}$ However, the current period is not the first decade in which Russian historians have studied the alternative regimes to Bolshevik political power; a power that existed in the country during the Russian revolution and the Civil War of 1917-1922. Among the state entities of this period, historians have shown a particular interest in regimes that were ruled by leftist parties, but that were opposed to the Bolsheviks. One of the attempts of right-wing socialists to propose their own version of the revolution took place in 1918 in the very heart of Russia - Ural - and grew into the largest anti-Bolshevik workers' uprising in Soviet history. At the heart of this uprising was Izhevsk - one of the most important industrial centres in the country. The study of the anti-Bolshevik workers' uprising in Izhevsk sheds light on both the nature of political forces that came into power in this particular town and general patterns in the development of the Russian Civil War.

Interest in the events that shook Izhevsk and the nearby town of Votkinsk has not faded in Russian historiography. On the contrary, interest has only grown over the years. This is no coincidence, as it was the working class - the proletariat - that Soviet ideology proclaimed to be the social foundation of the Bolshevik Party and its state. In the early period of the development of historical science in the USSR, the Izhevsk uprising was studied in the context of the workers' mass protests in Ural. In this region, the establishment of Soviet power was a very arduous process. The front between the White and Red armies shifted several times from west to east. Remaining at the epicentre of

1 Parts of this chapter have been translated from an essay that was published in German as "Der antibolschewistische Arbeiteraufstand in Iževsk. Probleme der Etablierung ziviler Machtorgane August bis November 1918”, Arbeit - Bewegung - Geschichte. Zeitschrift für historische Studien 7, no. 2 (2018): 139-16o. We are grateful to the editors of $A B G$ for their permission for this translation. The editors thank Gijs Kessler and Kevin Murphy for their help with matters of transliteration. 
the civil war, the Ural region saw many attempts by the local population to independently choose its own future. ${ }^{2}$ In the years of the formation of Soviet historiography, the events in Izhevsk from August to November 1918 had already attracted the most attention among the various instances of working class protest. ${ }^{3}$

In the studies by Soviet historians from the 1920s, some questions were quite boldly raised and discussed that were not entirely convenient for the ruling party. This was possible because at that time, a single ideology and unified view of the 1917 revolution did not yet exist in the UsSR. Among these fundamental questions was that of the reasons for the uprising. It was common to emphasize the influence of the Socialist Revolutionaries and Mensheviks on the development of events in Prikamye (the Kama region in Ural) that led to a split among workers. ${ }^{4}$ At the same time, in the 1920 it was still possible to find references to the mistakes made by the Soviet authorities themselves that potentially caused the Izhevsk uprising.

Among the problems discussed by Soviet historians were the inability of the local Bolshevik organization to appeal to the majority of Izhevsk workers, and its inability to work with mass proletarian organizations (such as trade unions), which ultimately resulted in their shift towards an anti-Soviet position. Furthermore, there were the harsh "ultra-left" measures by the Bolsheviks and their closest allies, in particular the Socialists-Revolutionaries Maximalists (sR s Maximalists). One example of the harsh actions by the Bolsheviks was their attempt at solving the food problem through the creation of prodotryads (food-requisitioning groups). There were numerous examples of the local authorities' incompetence, which was at the time highly likely to fuel the growing discontent of workers. For instance, Soviet historian A. I. Anishev linked the uprisings in the Ural and Volga region not to the activity of kombeds (committees of poor peasants) or the anti-Bolshevik propaganda of the right-wing socialists, but largely to the mass conscription for the Red Army that began in 1918. ${ }^{5}$ However, other historians of the epoch did not agree with Anishev's conclusions. Among these was A. P. Kuchkin, a participant in the Izhevsk events

2 N. Solonitsyin, ed., Oktyabr i grazhdanskaya voyna v Vyatskoy gubernii (Vyatka: Istpart Vâtskogo gubkoma $\operatorname{VKP}(\mathrm{b}), 1927)$.

3 N. Sapozhnikov, "Izhevsko-Votkinskoe vosstanie", Proletarskaya revolyutsiya, no. 8-9 (1924): 5-42.

4 For example, Izhevskv ogne grazhdanskoy voynyi, 1917-1918: Iz istorii revoliutsionnogo dvizheniia izhevskikh rabochikh (Izhevsk: Izd. Obl. komissii po provedeniiu desiatoı̆ godovshchiny Oktiabr"skoĭ revoliutsii, 1927).

5 A. I. Anishev, Ocherki istorii grazhdanskoy voynyi. 1917-1920 (Leningrad: Voenno-polit. akad. im. t. Tolmacheva RKKA i RKKF, 1925), 133, 138. 
and a prominent figure in the Soviet Union at the time, who wrote even more boldly about the reasons behind the uprising. He noted that in some Ural plants, certain Soviet leaders behaved in a way that completely discredited the Soviet government. They shot people left, right and centre, took bribes and interpreted the party programme "like criminals". Such circumstances, Kuchkin believed, made workers look forward to the arrival of the White Army. ${ }^{6}$

The next stage in the development of Soviet historical science began at the start of the 1930 s and ended during the second half of the 1950s. The political situation in these years negatively affected studies concerning the history of the workers' movements. As the conventional state-sanctioned version of the October Revolution crystallized, work on and objective study of the history of the working class diminished. The general tendencies in the development of historical science also affected the study of the history of workers' protest movements in the first months of the Soviet state's existence. Apart from a reduction in the number of publications about the history of trade unions, the number of works discussing the political struggle within them was also substantially reduced, as was serious discussion of the desire of certain trade unions to take the lead in anti-Bolshevik workers' protests. The works published about this issue were more propagandistic than academic. In those times, the official point of view was finally consolidated, and it suggested that any manifestation of opposition sentiments in the workers' movement was the result of petit bourgeois influence or the "subversive" and "counterrevolutionary" activity of the Mensheviks and Socialist Revolutionaries among workers. ${ }^{7}$ The same approach also dominated the historiography of the Izhevsk uprising. ${ }^{8}$ Its final evaluation was contained in the History of the All-Union Communist Party (Bolsheviks): Short Course, in which the uprising in Izhevsk was declared as having been a revolt by "Socialist Revolutionary oriented workers". 9

This development in the Soviet historiography of the workers' movement continued until the mid-195os. At this time, mentions of the Izhevsk uprising were very rare and more often than not, superficial. In Soviet historiography the point of view was firmly consolidated that the Izhevsk uprising was a result of the propaganda of the petit bourgeois parties of the SR s and Mensheviks, as

6 A.P. Kuchkin, “K istorii Izhevskogo vosstaniya”, Proletarskaya revolyutsiya, no. 6 (1929):153-162.

7 For example, A. Kazakov, I s'ezd i IV konferentsiya professionalnyih soyuzov (Moscow: Profisdat, 1933).

8 V.A.Maksimov, Kulatskaya kontrrevolyutsiya iIzhevskoe vosstanie (Izhevsk:Udpartizdat, 1932).

9 Istoriya Vsesoyuznoy Kommunisticheskoy Partii (bolshevikov). Kratkiy kurs. Pod redaktsiey komissii TsK VKP (b) (Moscow: Gos. izd-vo polit. lit-ry, 1938), 217. 
well as the supposed petit bourgeois nature of the majority of the local workers themselves. ${ }^{10}$ In a monograph published in 1967 in Izhevsk on the history of the revolution and civil war in the city, the workers' uprising was defined as an armed counter-revolutionary insurrection. ${ }^{11}$ In this publication, it was also noted that Constituent Assembly proponents in Prikamye were closely connected with the bourgeoisie and "leaned on the bayonets of the Czechoslovaks". ${ }^{2}$ Neither of these "facts" corresponded to the true events of the revolution: the Izhevsk plant was state owned, thus there was no high industrial bourgeoisie, and the Czechoslovak troops were very far away from Izhevsk and never entered the city.

At the same time, the discussion was resumed about the social specifics of Izhevsk workers in comparison with workers in other regions of Russia. A gradual formation of the working class was taking place in the Kama region, and its social profile combined modern industrial features and a strong sense of connectedness with the land in conjunction with forms of peasant farming. These factors were considered by Soviet historians as the reasons why workers in Izhevsk rose up to rebel against the Bolsheviks. ${ }^{13}$ However, Soviet historiography exaggerated the uniqueness of this phenomenon. The Izhevsk and Votkinsk workers' connection to the land was not something unique that distinguished them from the workers in other regions of the country; it was a universal phenomenon. There were continuous discussions among Soviet historians of the New Economic Policy about the social profile of the Ural workers, almost half of whom remained peasants; a trend that only ceased with the establishment of the Stalinist regime. ${ }^{14}$ A significant connectedness with peasant roots was a general characteristic of the Russian proletariat, even the workers in the Central Industrial Region that included Moscow and several neighbouring provinces of Central Russia. The characteristic features of the development of the Central Industrial Region were considered by one of the doyens of the Soviet historical school, A. M. Pankratova. ${ }^{15}$ Some other historians, such as V. Y.

10 For example, E. A. Ryabuhin, Vbor'be skontrrevolyutsiey (Pomosch trudyaschihsya Vyatskoy gubernii Vostochnomu frontu v1918-1919 gg.) (Kirov: Kirovskoe knizhnoe izdatel'stvo, 1959).

11 S. P. Zubarev, Prikamye v ogne (Izhevsk: Udmurtiia, 1967), 62, 64.

12 This refers to the Czechoslovak troops who were in Russian territory at the time of the October Revolution and who mutinied against Soviet power in the spring and summer of 1918.

13 S. P. Zubarev, Za respubliku Sovetov (Izhevsk: Udmurtiia, 1970), 125-126.

14 Istorik i vremya. 20-50-e gody XX veka: A.M. Pankratova (Moscow, 2000), 40-54.

15 A. M. Pankratova, "Tekstilschiki v revolyutsii 1905-1907 gg", in Rabochiy klass Rossii: Izbrannyie trudyi, ed. A. M. Pankratova (Moscow: Nauka, 1983). 
Laverychev, also noted these specific features with regard to the development of capitalist relations and classes in Russia. ${ }^{16}$

One of the key indicators showing the workers' continued relationship with the villages is the plots of land that many of them owned. This phenomenon is shown, for example, by published data from the professional census of 1918 . After analysing its results, historian A. G. Rashin proved that just prior to the revolution, on average 31.3 per cent of the workers in 31 provinces of Russia owned their own or their family's land. Another 20.9 per cent not only owned land, but also supported their household from it by themselves or with the help of their family. ${ }^{17}$ If for some reason workers lost their economic connectedness with the land, they often kept the personal connection, which included transferring part of their earnings to their relatives in the village. In particular, as the researcher O. Solovyov emphasizes, 94 per cent of the workers in Tsindelevskaya's manufacturing sector were peasants by origin, even by $1917 .^{18}$

As we can see, the social profile of Izhevsk workers was little different from that of their counterparts in the rest of Russia; a strong connectedness with the peasantry and small-scale land ownership. For the official Soviet ideology, the peasantry was a very conservative and even counter-revolutionary class. However, that begs the question of why there were no similar protests by workers against the Bolsheviks in the overwhelming majority of other Russian cities, where the connections between the workers and the peasantry were much stronger than in Izhevsk. Soviet historiography has been unable to answer this question.

\section{Emigrant Historiography and Historiography in Russia since Perestroika}

The historical scholarship produced by Russian emigrants was also far from objective in its study of the Izhevsk uprising. In the works of emigrant historians, the uprising became a symbol of the people's resistance to Bolshevism. ${ }^{19}$

16 V. Ya. Laveryichev, Monopolisticheskiy kapital v tekstilnoy promyishlennosti Rossii (19oo1917 gg.) (Moscow: Izd-vo Mosk. un-ta, 1963).

17 A. G. Rashin, Formirovanie promyishlennogo proletariata $v$ Rossii (Moscow: Izd-vo sotsial'no-èkon. lit-ry, 1940), 414-415.

18 O. A. Solovyov, "K voprosu o reaktsii Moskovskogo proletariata na fevralskie sobyitiya v Moskve", 1917 god v istoricheskih sudbah Rossii. Problemyi istorii Fevralskoy revolyutsii (Moscow: Izd-vo Prometey, 1922): 114.

19 A. G. Efimov, Izhevtsyi i votkintsyi (borba s bolshevikami 1918-1920 gg.) (Concord, CA: G. N. Blinoff, 1974). 
The contemporary historiographer from the Ural region, A. S. Vereschagin, emphasized in this regard that despite its many dissimilar approaches and assessments, the emigrant historiography was as much characterized by a politicized interpretation of the issue as its Soviet counterparts were. ${ }^{20}$

Nevertheless, emigrant authors with different political views contributed to the interpretation of the Izhevsk uprising. In addition to socialists, conservative authors - who were also often eyewitnesses and direct participants in the events - gave their assessments of what took place in the Kama region in 1918. Because of their direct role, one of the most important issues facing the emigrant historiography was the search for those responsible for the defeat of the uprising; a search often ending in mutual reproaches and accusations. The nature of the movement was interpreted in different ways. For Menshevik historians and memoirists, the Izhevsk uprising was seen as a continuation of the struggle for the Constituent Assembly and democracy. ${ }^{21}$ However, their opponents on the political right sought to emphasize the broad, all-encompassing character of the uprising, denying the leading role of socialists in its preparation. ${ }^{22}$ At the same time, the disagreements of various emigrant historians disappeared when it came to the anti-Bolshevik orientation of the Izhevsk workers' protest.

During and after the years of Gorbachev's perestroika, several new publications about the Izhevsk uprising appeared. Among the most recent works specifically focusing on the question of workers' protests at the birth of the Soviet regime, the monograph by the Izhevsk historians P. N. Dmitriev and K. I. Kulikova deserves a mention, as it provides a wide overview of the IzhevskVotkinsk uprising. ${ }^{23}$ However, this work still contains many of the same myths inherent in earlier Soviet historiography, despite being based on sources in several local archives, primarily from Izhevsk. Nevertheless, the range of problems highlighted is much broader than any others from earlier historiography, whether Soviet or emigrant. In particular, these two Izhevsk historians raised more boldly than before the issue of harsh "ultra-left" measures inherent in the policies of the Soviet government, as well as the problem of the heterogeneity

20 A. S. Vereschagin, "Paradoksyi istoriografii Izhevsko-Votkinskogo vosstaniya", in Akademik P.V.Volobuev. Neopublikovannyie rabotyi. Vospominaniya. Stati, ed. P. V.Volobuev, (Moscow: Ross. akad. nauk, 2000), 389 .

21 I. G. Upovalov, "Rabochee vosstanie protiv sovetskoy vlasti", in Ural i Prikame (Noyabr 1917 - yanvar 1919). Dokumentyi i materialyi, ed. M. S. Bernshtam (Paris: YMCA Press, 1982), 396-421.

22 S. P. Melgunov, Tragediya admirala Kolchaka (Belgrade: Russkaia tipografia, 1930), 108.

23 P. N. Dmitriev and K. I. Kulikov, Myatezh v Izhevsko-Votkinskom rayone (Izhevsk: Udmurtiya, 1992). 
of political forces that supported Soviet power in Izhevsk. This issue was covered in greater detail in a book by an Izhevsk historian, S. L. Bekhterev. He was especially interested in the role of a small but very radical party, the SocialistRevolutionaries Maximalists, in the history of the Kama region during the Russian revolution. Bekhterev's work was produced at a time when the opportunity to write more objectively about the so-called "petit bourgeois parties" had grown, a notion that the previous generations of Soviet historians had used to identify not only Mensheviks and right-wing Socialist-Revolutionaries, but also left-wing Socialist-Revolutionaries and SR s Maximalists. ${ }^{24}$

The beginning of the twenty-first century was marked by the publication of several other works on the history of Izhevsk, including the events that took place in the region during the civil war. Despite the fact that more than a century has passed since the studied events, the works of contemporary authors are still not free from political sympathies for certain participants in the revolution in Prikamye. At the same time, it should be said that this does not prevent further study of the events of the uprising in 1918, and of their causes and consequences. In fact, it may even prompt these inquiries further. Another important step towards restoring an accurate image of the political process in Izhevsk and the whole Kama region in 1918 was the recent publication of the book by A. V. Korobeynikov, Participants of the Izhevsk uprising from August to November $1918 .{ }^{25}$ Korobeynikov is also the author of some earlier works on the topic. ${ }^{26}$ Another Izhevsk historian already mentioned above, P. N. Dmitriev, is actively continuing his research. His post-Soviet works are perhaps the most informative and objective of all the studies that have been published in Izhevsk this century. Issues that previously remained outside the field of vision of Russian historians have been covered by him, based on new archival material. ${ }^{27}$

24 S. L. Behterev, Esero-maksimalistskoe dvizhenie v Udmurtii (Izhevsk: Udmurtskii institut istorii, iazyka i literatury UrO RAN, 1997).

25 A. V. Korobeynikov, Uchastniki Izhevskogo vosstaniya avgusta - noyabrya 1918 g.: ih sudbyi $i$ spiski po arhivnyim fondam Sovetskoy militsii (Institut kompyuternyih issledovaniy, Izhevsk, 2016).

26 A. V. Korobeynikov, Volzhskaya flotiliya protiv narodnoy armii (osen' 1918 g.) (Idnakar, Izhevsk, 2012). A. V. Korobeynikov, Votkinskaya narodnaya armiya $v 1918$ g. (Idnakar, Izhevsk, 2013).

27 P. N. Dmitriev, "Partiyno-politicheskaya sistema Udmurtii v usloviyah stanovleniya sovetskoy gosudarstvennosti (oktyabr 1917 - vesna 1918 gg.)," Rossiyskaya gosudarstvennost:urovnivlasti. Istoricheskaya dinamika. Materialyi Vserossiyskoynauchno-prakticheskoy konferentsii (Izhevsk: Izdatelskii dom "Udmurdskii universitet", 2001). P. N. Dmitriev, "Sotsialnyiy oblik rabochih Udmurtii v pervyie desyatiletiya XX v.: sotsialno-byitovyie, 
Studies by other authors have been published in recent years. They have raised issues such as the role of the Izhevsk uprising among the various workers' protests of $1918,{ }^{28}$ the particularities of the Soviet account of the Izhevsk uprising's social nature, ${ }^{29}$ the role of the so-called "third force" ${ }^{30}$ in the events of the revolution in the east of Russia, ${ }^{31}$ the role of Izhevsk rebels in the Kolchakov army after their retreat to the East in the fall of $1918,{ }^{32}$ and the production of weapons in rebel-occupied plants in the city of Izhevsk. ${ }^{33}$ In addition, collections of documents also started to be published in Russia, including archival documents dedicated to the Izhevsk uprising and the preceding period. ${ }^{34}$ The most important recent documentary publication is a voluminous work written by Izhevsk historians and archivists to mark the 1ooth anniversary of the Russian Revolution. This group of authors set themselves the task of presenting, as far as possible, a complete and objective picture of the events of 1917, with much wider coverage of the socio-political, economic and cultural life of the Udmurt Krai during this period. About 80 per cent of the documentary material in the collection has never been published before. ${ }^{35}$

This array of recent publications allows for serious advances to be made with regard to many issues concerning the history of the Izhevsk uprising. It also allows us to more carefully address the questions already posed in earlier

proizvodstvennyie, politicheskie aspektyi", in Rabochie Rossii. Istoricheskiy opyit i sovremennoe polozhenie, ed. D. O. Churakov (Moscow: Ėditorial U RSs, 2004), 149-164.

28 N. A. Zayats, "O fenomenalnosti Izhevsko-Votkinskogo vosstaniya", Idnakar: metodyi istoriko-kulturnoy rekonstruktsii, no. 1 (2013): 34-48.

29 A. V. Ivanov, "Sotsialno-politicheskie aspektyi Izhevsko-Votkinskogo vosstaniya 1918 goda v trudah sovetskih istorikov 1920-30-h godov", Vestnik Udmurtskogo universiteta, no. 3 (2012): 47-54.

$30 \quad$ Neither Bolsheviks nor Whites, but usually right-wing socialists.

31 I. P. Klimov, "Deyatelnost pravitelstv 'demokraticheskoy kontrrevolyutsii' Sibiri i Urala na zheleznodorozhnom i vodnom transporte vesnoy-osenyu 1918 goda", Noveyshaya istoriya Rossii, no. 2 (19), (2017): 53-67. I. V. Shvets, Grazhdanskaya voyna v Sibiri i na dalnem Vostoke Rossii: borba respublikanskoy i monarhicheskoy tendentsiy (1917-1922 gg.), (Dissertatija, Chabarovsk, 2007).

32 A.V.Posadskiy, "Izhevskaya brigada v boyu 9 maya 1919 g. glazami belyih i krasnyih", Sibirskiy istoricheskiy almanah. Tom 2. Sibir na perelome epoh. Nachalo HH veka (Krasnoyarsk: Verso, 2012), 134-137. E. G. Renyov, "Vospominaniya D.I. Fedichkina kak istochnik po izucheniyu Izhevskogo antibolshevistskogo vosstaniya (8 avgusta - 8 noyabrya 1918 g.)”, Vestnik Udmurtskogo universiteta, no. 3-5 (2011): 158-161.

33 "Bezoruzhnoe vooruzhyonnoe vosstanie: proizvodstvo vintovok na izhevskih zavodah vo vremya antibolshevistskogo vyistupleniya", Vestnik Rossiyskogo universiteta druzhbyi narodov. Seriya: Istoriya Rossii, no. 1 (2013): 32-48.

34 Izhevsko-Votkinskoe vosstanie, ed. V. Zh. Tsvetkov (Moscow: Posev, 200o).

"1917 god v istorii Udmurtii". 
historiography, and to identify new problems that were invisible to historians in the past. In particular, it is possible to examine in a more detailed and objective way the development of the political situation in Izhevsk from May to November 1918, the evolution of the rebellion's authorities, the main aspects of their internal policies, and the causes of instability and the defeat of the antiBolshevik forces.

As a result of the ongoing political struggle, disputes and compromises in the spring and summer of 1918, two political blocs finally formed in Izhevsk. The Mensheviks and right-wing SR constituted the right-wing coalition, which opposed the power of the Soviets. In the Soviets, they saw not the embodiment of state power, but only the social-class agents of proletarian self-organization and elements of civil society. The slogan of the right-wing socialists was the re-establishment of the Constituent Assembly and self-governance through zemstvos (local councils for rural self-government), which had existed before the revolution. The left-wing coalition mainly consisted of the Bolsheviks and the SR S Maximalists, with both standing firmly on a platform of Soviet power. ${ }^{36}$ However, the differences in their understanding of the further goals of the revolution and the ways to achieve them made the left-wing bloc fragile. There were conflicts between the Bolsheviks and the SR s Maximalists at times, sometimes even in the form of armed confrontation between the two parties. Furthermore, an alliance with the even more radical SR s Maximalists prompted Izhevsk Bolsheviks to enact many radical measures that were unpopular among the workers and inhabitants of the villages around Izhevsk.

\section{"Power to the Soviets, Not the Party!"}

By May 1918, the right-wing socialists had finally managed to seize the initiative. The bloc of right-wing SR s and Mensheviks sharply intensified their criticism of the Bolsheviks' policy after the Eighth Party Council of the Party of Socialist Revolutionaries in Moscow in mid-May 1918. The decision was taken to launch an armed struggle against the Bolsheviks. ${ }^{37}$ Emissaries of the Central Committee of the Party of Socialist Revolutionaries rushed to different cities in the east of the country, and Izhevsk did not escape their attention. In the summer of 1918, two members of the SR s Central Committee, N. N. Ivanov and

36 S. L. Behterev, Esero-maksimalistskoe dvizhenie v Udmurtii, 52, 57.

37 Rossiyskiy gosudarstvennyiy arhiv sotsialno-politicheskoy istorii (RGA SPI), F. 274. Op. 1. D. 1. L. 34 . 
I. I. Teterkin, arrived there. ${ }^{38}$ The positions of the opponents of Soviet power in Izhevsk were significantly strengthened as a result of the Urban Union of Front-Line Soldiers joining their ranks, which brought together soldiers, officers and other veterans of the First World War. ${ }^{39}$ Initially, the union was concerned with social support for its members, but gradually it also became involved in the political struggle on the side of the Socialist-Revolutionaries and Menshevik bloc. Although formally the leadership of the union included ordinary soldiers and non-commissioned officers, in reality its activity was controlled by an active officer core, which was even more hostile to the Bolsheviks than the official right-wing socialist opposition. ${ }^{40}$ In the re-election of the Izhevsk Council, the Bolsheviks were defeated twice: at the end of May and at the end of June. While in May they had managed to resolve the situation peacefully, in June, with the help of reinforcements arriving from Kazan, they dispersed the council. Arrests began, and in total, about one hundred people were detained, including deputies of the new council and leaders of opposition parties and organizations. ${ }^{41}$ Power was initially put into the hands of a new executive committee, in which the Bolsheviks and the SR s Maximalists prevailed, and subsequently the Izhevsk Military Revolutionary Command Staff, headed by the Bolshevik, S. I. Kholmogorov. ${ }^{42}$

Izhevsk Bolsheviks repeatedly informed people in the capital about the situation in the city. In particular, S. I. Kholmogorov, who in his report to the People's Commissariat of Internal Affairs, stressed that if the Izhevsk plants were not paid the most serious attention, they would very soon turn into a major threat to the Soviet republic. After all, Izhevsk was a city with an arms industry, and the weapons produced there could have fallen into the hands of anti-Soviet forces. ${ }^{43}$ However, the warnings from the Izhevsk Bolsheviks were dismissed. Indeed, after the fall of Kazan following attacks by the Czechoslovak Legion of the French Army, the high command carried out a full mobilization in Izhevsk and sent the remaining forces of the Izhevsk communists to the front. Together with the Bolsheviks, the main forces of the SR s Maximalists

38 Tsentralnyiy gosudarstvennyiy arhiv Udmurtskoy Respubliki (TsGA UR), F. r-1061. Op. 1. D. 17. L. 11.

39 P. N. Dmitriev, Soldatskie soyuzyi v Udmurtii. Kanun grazhdanskoy voynyi (formirovanie, sotsialnyiy sostav, otnoshenie s partiyami) (Izhevsk: Muzey - Istoriya i sovremennost, 2000), 232-248.

40 Tsentr dokumentatsii noveyshey istorii Udmurtskoy respubliki (TsDNI UR), F. 350. Op. 49. D. 6. L. 1.

41 TsDNI UR. F. 35o. Op. 3. D. 14. L. 13-14.

42 Izhevskiy zaschitnik, 23 August 1918.

43 Gosudarstvennyi Archiv Rossiyskoi Federatsii. F. 393. Op. 1. D. 40. Ll. 314-319. 
were also dispatched to fight the mutiny by the Czechoslovaks. Only a few dozen Red Army soldiers and policemen remained in the city. This moment was used by the anti-Soviet opposition for a coup attempt. ${ }^{44}$

The Union of Front-Line Soldiers took up the role of the main force of the revolt. With about four thousand members, many with hidden weapons, the union was a real political force. However, the uprising could hardly have succeeded if the factory workers had joined the other side. Most of the workers showed passivity, while a number of them not only supported the uprising, but took an active part in it. Long before the Kronstadt uprising of 1921, the Izhevsk workers had raised their flag with a slogan that would become a symbol of democratic resistance to Bolshevism: "Power to the Soviets, not the party". 45 On 8 August 1918, power in the city was seized by the rebels. ${ }^{46}$ Soon after, on 17 August, forces from Izhevsk occupied Votkinsk, where they were also supported by local workers and the Votkinsk Union of Front-line Soldiers, and on 30 August the county (uezd) centre, Sarapul, also fell. ${ }^{47}$

\section{Evolution of the Rebellion's Statehood}

The first issue the rebels faced after their victory was the need to organize power. One of the rebel military leaders, Colonel D. I. Fedichkin, described the first steps: "At the end of the shootings [the mass shooting of Bolsheviks on the day of the uprising], silence settled over Izhevsk. Civil authority, which had previously belonged to the Bolsheviks, now passed into the hands of the Izhevsk Soviet of Workers' Deputies". ${ }^{48}$ Fedichkin refers here to the re-establishment of the city council, which had been disbanded by the Bolsheviks and the SR S Maximalists just three weeks before.

In accordance with the outlined plan and the agreements that had been reached, the executive committee of the Izhevsk Council and its presidium were renewed. The members of the new presidium included the Menshevik B. N. Kutsenko and local merchants Tyulkin, Sannikov and Gorev. Along with them, the presidium was joined by a former member of the Constituent Assembly from the Vyatka province, right-wing Socialist-Revolutionary V. I. Buzanov, as well as Soldatov, chairman of the Union of Front-line Soldiers of

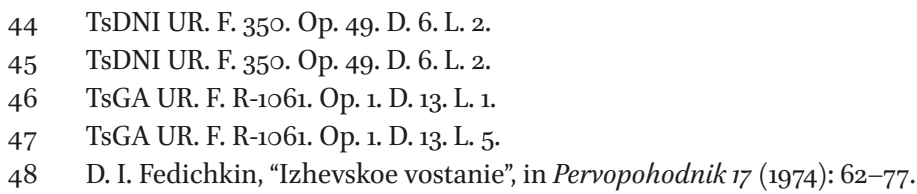


Izhevsk. ${ }^{49}$ Buzanov was involved in the work of the council at the insistence of the executive committee, and also the Command Staff of the Union of FrontLine Soldiers. ${ }^{50}$ Later, a new election for the council was announced. Needless to say, the Bolsheviks, the Socialist-Revolutionaries Maximalists and the anarchists were not allowed to stand in the elections, which were held according to the well-known system of trehvostka (three-tail) ${ }^{51}$; the same way as elections to the Constituent Assembly. ${ }^{2}$

It should be noted that the restoration of the council's power in Izhevsk took place after the pre-October institutions of power had been restored in other anti-Bolshevik territories. The power of the Izhevsk council was, of course, far from absolute: from the very beginning, the Command Staff of the Union of Front-Line Soldiers and of the People's Army stood behind it. The Votkinsk council became even more dependent on the military authorities; its executive committee taking many decisions based on the instructions of the head of the Votkinsk Command Staff, G. N. Yuriev, as shown by documents. ${ }^{53}$ Nevertheless, the reliance of the revolt's leadership on the workers' demand "Power to the Soviet, not the party!" should be recognized as the key feature of the events of the summer of 1918 in Prikamye. Almost everywhere throughout the rest of Russia at that time, the overthrow of the Bolsheviks was accompanied by the overthrow of Soviet power, whereas by contrast, in Izhevsk the overthrow of the Bolsheviks led to a brief revival of the Soviet power.

Such a situation was of course temporary, because the existence of a central anti-Bolshevik government in Samara implied the unification of state structures in the regions under its control. Therefore, the period for which the power of the democratically-elected workers' council was restored in Izhevsk turned out to be extremely short. On the day when the city of Votkinsk joined the revolt on 17 August, civil authority was handed over by the Izhevsk Council to the so-called Committee of the Members of the Constituent Assembly in Prikamye, or Prikomuch. A lot is unclear about the handover of power to the Prikomuch, but the general outline of the events can be based on available circumstantial evidence. In the period when the new Soviet was formed, there

49 N. Solonitsyin, "About the history of the Civil War in the province", in Oktyabr i grazhdanskaya voyna $v$ Vyatskoy gubernii. Sbornik statey $i$ materialov, ed. N. Solonitsyin (Vyatka: Istpart Vâtskogo gubkoma VKP(b), 1927), 40.

$50 \quad$ Izhevskiy zaschitnik, 23 August 1918.

51 TsGA UR. F. R-1061. op. 1. D. 17. L. 20-21.

52 V. G. Lekomtsev. K istorii Votkinskogo zavoda: Mezhdousobnaya voyna (1918-1919 godyi) (Votkinsk: Russkaîa gazeta Udmurtiimurtii, 1998), 45. 
were negotiations between the revolt's commanding staff and Buzanov - a member of the constituent assembly of the Vyatka Krai - about the creation of a firmly anti-Bolshevik government. Colonel A. A. Vlasov and captain N. Y. Tsyganov offered Buzanov the opportunity to form a committee of the constituent assembly, similar to the one in Samara, or to take supreme authority as the only member of the constituent assembly in the territory of the revolt. Buzanov flatly refused to take personal responsibility for the uprising, but promised to raise the issue of creating a particular collegiate authority at a meeting of the city committee of the SR s. The meeting between Vlasov, Tsygankov and Buzanov was private and was not recorded anywhere. However, the meeting of the SR s' city committee promised by Buzanov failed to take place. Buzanov did manage to speak personally with some members of the committee and gain their consent. ${ }^{54}$

The Prikomuch was practically the same as it was in Samara, and considered itself as the local power structure. It was announced that the city of Izhevsk was a territory under the "power of the Committee of the All-Russian Constituent Assembly, temporarily located in the city of Samara". It was declared that "all civil and military authorities in Izhevsk recognize the Committee as the sole and legitimate Supreme Power in Russia and consider themselves to be completely subordinate to it". It was also decided that the seat of the committee should be in Izhevsk. In Votkinsk and Sarapul, also under the control of the rebels, special commissioners were appointed as commissars. An agitation and education bureau was formed under the committee, immediately calling on the population to rise up in defence of the "gains of the February revolution and the Constituent Assembly". It was proclaimed that the local government in Izhevsk would act "to defend all civil liberties and true democracy of the people". ${ }^{5}$

New authorities were also forming in other settlements occupied by the rebels. For example, in Votkinsk the handover of power to the Prikomuch was carried out with the support of public opinion. A special meeting of citizens was held in the city, where the question of the organization of power was discussed. At the meeting, people agreed about the violent nature of the establishment of the Soviets' omnipotence in October 1917, emphasizing that all anti-Bolshevik uprisings in the country were under the banner of the Constituent Assembly. Based on this, the assembly concluded that "the Committee of Members of the Constituent Assembly, temporarily staying in Samara, is in

55 Izhevskiy zaschitnik, 1 September 1918. 
this particular situation the most acceptable and obvious source of power for the masses". Following the discussion, a resolution was adopted in which it was stated in the most unequivocal manner that "the power of the Soviets is over". Further, the resolution stated that in Votkinsk itself, as well as in Izhevsk and the surrounding areas, full power would be temporarily handed over to the Prikomuch, the local representative of the all-Russian authority of the Samara Committee to Save the Constituent Assembly.

At that time, questions about the organization of power were also being discussed in the town of Sarapul in the same district. After the beginning of the uprising, Sarapul lost its former significance as the local administrative centre, and political decisions were by then being dictated from Izhevsk. Thus, on 2 September, the recreated City Duma gathered in Sarapul. Chairman P. P. Mikhailov, who had been appointed from Izhevsk, delivered a speech to the members of the duma. At his suggestion, a decision was made that the supreme power in the city should be temporarily handed over to the executive body of the city administration, the Uprava (City Council). All the funds received for the maintenance of the People's Army in Sarapul were to be at its disposal. However, at the first request from the Command Staff of the People's Army, the city Uprava was obliged to transfer any required funds, with the army acknowledging the receipt of the transferred amount. Under the Uprava, a special body was created to raise funds: the Financial Commission. The elected members of this commission were two members of the city duma (K. G. Solov and G. E. Kulikov), the chairman of the Sarapul Uprava, S. F. Yermolin, and two representatives of the central factory workers' committee of Sarapul. ${ }^{56}$

A republican government structure in the rebel region was finally formed by mid-September. The formation of the Prikomuch was also finalized, with Buzanov becoming its chairman. In addition to Buzanov, the committee included A. D. Karyakin and N. I. Evseev, and from 9 September 1918, the signature of K. S. Shulakov also appeared on the documents. In some sources, the expression "the top four" was used for the new authority. On this same date, the rebel government implemented a comprehensive administrative reform in order to regularize the system of governance in the region, and all the measures planned in this regard were described in great detail in Decree No. 4, adopted that day. ${ }^{57}$

The decree began with a declaration that "the power of the Soviets and their Committees is abolished". The Soviets themselves were spared, but their

$56 \quad$ Izhevskiy zaschitnik, 5 September 1918.

57 TsDNI UR. F. 35o. op. 6. D. 5o. Svyazka 2. L. 16-20. 
actual functions were reduced to proletarian organizations of the workers and the working peasantry. The decree fully restored the pre-October order, and city and local governments were declared as regulatory bodies. They were ordered to act "on the strict basis of the Provisional Government's resolutions concerning rural and city self-government". In the villages, instead of the dispersed Soviets, it was entrusted to village gatherings, "until the general resolution of the issue of rural management on a nationwide scale", to temporarily elect a committee or a person to take over the functions previously performed by the starosta, the village headman. All Soviet institutions and their members were instructed to "immediately hand over their affairs and the funds and valuables they have $[. .$.$] to the restored local self-government body". Workers$ in Soviets were also obliged to assist in the restoration of local government. The restoration of the zemstvos and self-governing city bodies was to be based on universal, direct and equal suffrage and a secret ballot. The decree by the provisional government concerning the township (volost') and county (uezd) zemstvos was to form the basis of the elections, in which all men and women who had reached the age of twenty and were residing in the villages controlled by the rebels were eligible to participate.

However, the period during which the democratic authorities ruled the region did not last much longer than the activity of the altered Soviet. Significant changes took place within the upper ranks of the rebels shortly after the dissolution of the Komuch and the creation of the Ufa Directory on 23 September. It is repeatedly noted in memoirs and historical literature that in the autumn, the representative of the local Udmurd population of Evseev instead became the head of the rebel republic of Buzanov. The reasons for this change were not explained at the time, although they were relatively trivial. On 14 October 1918, Evseev began to govern on the basis of the mandate given to him by the Central Government of Russia: the Directory. ${ }^{58}$ Special commissioners of Evseev were sent to villages under the rule of Izhevsk, and by then all civil authority had been concentrated in their hands, although military power was still held by the command staff. ${ }^{59}$ Based on available sources, we can assume the authorities in

$5^{8}$ TsDNI UR. F. 35 o. op. 6. D. 5o. Svyazka 2. L. 41. The Ufa Directory was a temporary allRussian government, founded at a government meeting in Ufa by the anti-Bolshevik coalition of representatives of the Komuch and the Omsk provisional government.

59 The Izhevsk and Votkinsk People's Armies initially existed independently of each other, and their command staff also acted separately. Rebel forces later merged in the United People's Army of Prikamye, and the Izhevsk army's command staff became the General Command Staff of Prikamye. A. A. Karevskiy, "K istorii antibolshevistskogo vosstaniya v Izhevske i Votkinske: vooruzh Yonnyie formirovaniya Prikamya letom—osenyu 1918 g”., 
Izhevsk remained in this form until their forced withdrawal to the other side of the river Kama under pressure from the advancing Red Army.

Three stages can therefore be clearly distinguished in the evolution of the rebel republic: a period of Soviet administration, a period of civil administration and a period of one-person rule. The fact that civil authority at all stages of its development coexisted with military power should also be noted. Moreover, military power was initially dominant - or at least as powerful as civilian power - only temporarily disappearing into the shadows. Obviously, this peculiar evolution of the non-Bolshevik regime in the Kama region was determined by the general circumstances of the civil war, which eliminated the specifics behind the formation of the local authorities that emerged in the first weeks of the Izhevsk uprising. In those years, both in the Soviet and in the White Army territories, democratic and civilian institutions gave way to authoritarian and military ones. The ideological principles that had guided the right-wing socialist leaders of the uprising were soon forgotten in the face of harsh reality. At the same time, the rebel authorities were trying to implement these principles not only with regard to the structure of local administrative bodies but also the policies they pursued in the territories under their control. This is a subject that needs to be discussed separately.

In the past, the study of the policies of Izhevsk's new rebel authorities was largely limited to examining the creation of the People's Army in Prikamye, as well as terrorism against the Bolsheviks. This choice was determined not only by ideological clichés, but also by the nature of the question and the available sources, as these two aspects of the rebel regime's policies are well-reflected in available documents. In addition, the People's Army in Prikamye subsequently joined the Kolchak army and became one of its most capable units. As for the regime of terror carried out in Izhevsk, it was indeed particularly cruel, even by the standards of those harsh times. ${ }^{60}$ It is not only Soviet authors who wrote

in Izhevsko-Votkinskoe vosstanie, ed. A. A. Karevskiy, K. A. Kulagin and D. O. Churakov (Moscow: Posev, 2000), 5-12.

6o In this regard, it is worth mentioning not only its scale and organized character, but also for example, the most common methods of execution: the convicts were not shot, but bayoneted to death. After the Red Army units entered Izhevsk, the graves of those killed by rebels were opened, and 50-6o stab wounds and other signs of beatings and torture were found on the corpses. See, for example: TsGA UR. F. P-1061. Op. 1. D. 37. Ll. no. 5, 7 and others. 
about the numerous victims, but also the rebels themselves. For instance, A. Y. Gutman reported of "hundreds arrested in improvised detention houses".61 In addition, about 3,000 prisoners were kept on barges adapted as temporary prisons. ${ }^{62}$

It would, however, be wrong to reduce the activities of the rebel government of Izhevsk only to military and police measures. Normal provincial life in the city did not stop for a minute, and the new authorities had to maintain and regulate it. Various civilian institutions continued to operate, and medical assistance was provided. The religious life of city dwellers and workers was reviving, and religious processions were held on special occasions. Schools began to operate in the autumn, and a special decree by the temporary Prikomuch was devoted to the new academic year. It exempted teachers and students from military service and ordered that the educational institutions temporarily employed for military needs should be vacated. ${ }^{63}$

The main concern of the rebels was to maintain production at the Izhevsk plant, because the military products made there were of strategic value. In addition, the participation of some workers in the uprising called for an active labour policy by the rebel authorities. In accordance with the order of $11 \mathrm{Au}-$ gust 1918, a new board took over the management of the plant. Apart from its managing director, Y. I. Kanevsky, and administrative and economic director, G. K. Vilma, there were also three representatives from the workers. The order noted that the workers' representatives were only introduced temporarily until the elections. ${ }^{64}$

The re-election of these representatives played an important role in strengthening the rebel government. However, the details also show an increase in absenteeism and indifference among the workers. Only 4,137 workers took part in the elections, and 325 people left the ballot paper blank. D. P. Krupin $(1,512$ votes), V. I. Buzanov (1,394 votes) and P. A. Baryshnikov (1,291 votes) were elected as members of the collective management of the Izhevsk plants. ${ }^{65}$ Subsequently, when Buzanov became a member of the Prikomuch, V. E. Korepanov took his place on the board, having come fourth in the elections with 288 votes for his candidacy ${ }^{66}$ Initially, apart from the plant's administration, the Soviets

61 "Beloe delo. Letopis beloy borbyi. Berlin", 3, (1927), in Ural i Prikame (Noyabr 1917 - yanvar 1919): Dokumentyi i materialyi, ed. M. S. Bernshtam (Paris: Rosspen, 1982), 385.

62 See also, TsGA UR. F. R-6og. Op. 1. D. 2. Ll. 1-110, TsGA UR. F. R-6o9. Op. 1. D. 3. Ll. 1-139, and TsGA UR. F. R-6og. Op. 1. D. 4. Ll. 1-126.

63 Izhevskiy zaschitnik, 18 September 1918.

64 TsGA UR. F. R-543. Op. 13. D. 13. L. 1.

65 TsGA UR. F. R-543. Op. 13. D. 13. L. 9.

66 TsGA UR. F. R-543. Op. 13. D. 13. L. 3 o. 
dealt with the issues related to the organization of labour in the rebel region. Somewhat later, on 30 October, a labour department was established directly under the control of Extraordinary Commissioner Evseev in order to centralize labour policies, with M. N. Martynov appointed as the head of the labour department. ${ }^{67}$

Along with the new management of the plant, basic provisions for the management of production were developed to replace those that had existed under the Bolsheviks. For instance, a plan was outlined with the main provisions for management of the artillery plant, containing items specifically addressing the rights of workers' representatives in this regard. The proposal was to elect these representatives according to "the four pillar formula": on a democratic basis. However, workers' rights were limited in favour of the management. In the document, for example, it was specifically noted that "the workshops, the Economic Committee, forest areas, railways and other departments of the factories are to be handled by the management with full responsibility, and therefore all commissioners and collegiate bodies in the factories must move up the affairs to the heads of the relevant departments". ${ }^{68}$

In order to improve the functioning of the plants, the authorities in the rebel region implemented several populist measures. For example, in the order for the Izhevsk Arms and Steel Plants No. 28 of 5 September 1918, it was announced that on the days when the plant was not operating (from 8 to 10 August) workers would still be paid. In addition, the fixed output system was abolished, meaning that everything workers produced in excess of the norm was to be paid additionally. ${ }^{69}$ Moral as well as economic incentives were involved. In one of the special appeals of the Prikomuch to the workers, it was emphasized that Izhevsk plants were "the most powerful means" in the fight against "enslavers of the Russian people ... for the final triumph of democracy of the people". It was further claimed that "the workers who remained at the plant should remember that by increasing labour productivity in the production of the necessary weapons they directly contribute to saving our Motherland".70

To meet the needs of workers, the new authorities kept wages at the level they had been at under the Bolsheviks. The decrees of the Soviet government concerning working conditions, working hours and social guarantees were also not touched, and all of them remained in force. For example, the

67 TsGA UR. F. R-46o. Op. 1. D. 2. L. 148.

68 TsGA UR. F. R-543. Op. 13. D. 13. L. 1-1 ob.

69 TsGA UR. F. R-543. Op. 13. D. 13. L. 28.

$70 \quad$ Izhevskiy zaschitnik, 15 October 1918. 
Izhevsk arms plant continued to operate three 8-hour shifts, as it had done before, although it would have benefitted the interests of the defence industry to have increased the working day. The rebel authorities limited themselves to introducing compulsory overtime work, although this innovation was initially introduced only in mid-October and was limited to workshops lagging "in the supply of necessary items for the production of rifles".71 Many of the economic decisions made by the rebel leadership bore obvious traces of egalitarian tendencies characteristic of the Russian revolution of 1917. This was expressed primarily in the fact that the command ranks, the soldiers and the workers were to receive an equal monetary allowance. On this occasion, the Prikomuch adopted a special decree, ordering "to pay everyone the same salary, 420 rubles a month, to all those working in the factories, to all who fought against the Bolsheviks by arms, and all the city and factory workers without distinction of positions and seniority".72

After the moderate socialists took power, the position of the trade unions changed. The Mensheviks - together with the right-wing Socialist Revolutionaries who shared their stance in this matter - advocated the independence of the trade unions. This question was discussed in particular at the general meeting of the Delegate Council of the Votkinsk Union of Metalworkers. Having delivered a report on this issue, the prominent Menshevik I. G. Upovalov condemned the practice of the Bolsheviks that had allowed the trade unions to manage the process of production. He stressed that "the Union was turned not into an organization of the economic or political struggle of the workers but into some kind of government agency that fights against the working class and does not protect its interests", and he called for an end to this practice. Members at the meeting supported the resolution proposed by the Mensheviks, which ended with the words: "We, the workers of the Votkinsk plant, delegates of the Metalists' Union, consider it necessary that the trade union must make a break with all power, no matter where it comes from, i.e. must stay neutral and stand solely and exclusively to defend the interests of the working class in its struggle against the oppressors". ${ }^{73}$ Pursuing the line of "independence", the Union of Metalworkers sometimes spoke out against the rebel authorities of the region, even occasionally engaging in sharp conflicts with them. ${ }^{74}$ The positions of the workers' organizations were especially strong in Sarapul. The orders of the military authorities there had to be signed

71 Izhevskiy zaschitnik, 15 October 1918.

72 Fedichkin, Izhevskoe vostanie.

73 Votkinskaya zhizn, ${ }_{15}$ September 1918.

74 TsGA UR. F. R-1061. Op. 1. D. 21. L. 16o ob. 
by the delegates of the factory committees, without which no decisions had any legal force. ${ }^{75}$

At the same time, because the situation was becoming more difficult on all fronts, completely different approaches began to prevail in the labour policies of the rebel authorities. "This terrible hour of protecting our interests requires a great effort", read one of the proclamations of the Union of Front-Line Soldiers, meaning that "at the present moment we cannot adhere to all the norms protecting labour in peacetime". ${ }^{76}$ These calls were not only made on paper, as democratic labour rights actually came to be curtailed over time. For example, overtime work became mandatory. Order No. 63 of the Chairman of the Board of the Izhevsk Plant, dated 18 October, stated: "In view of the impossibility of returning workers from the front to the plant for military reasons and the extreme necessity of rifles, a 2-hour overtime has to be introduced in all workshops where less than 1,000 articles are produced".77 Overtime work was not paid, but was listed as arrears. Workers' salaries were not paid either. At best, they were given only two-thirds of the amount they were due, and the rest was withheld. When this measure was introduced in the first half of September it was perceived by many as temporary, but the situation in the payment of wages to workers did not improve in the second half of the month, or in October. ${ }^{78}$ Measures in the field of labour generally became draconian in the last days of the existence of the rebel republic in Izhevsk, as evidenced by the factory order dated 28 October 1918 and signed by the Commander-in-Chief of the Prikamsky in the Yuriev district and the plant's managing director, Y. Kanevsky. This order effectively introduced the mobilization of factory workers, concluding categorically: "Failure to appear at work will be considered as non-fulfilment of the combat order". ${ }^{79}$ The policy in relation to workers' organizations was also toughened. For instance, the leader of the Votkinsk Union of Metalworkers, A. K. Malkov, was actually expelled from the city for his position, which had become undesirable to the military authorities. ${ }^{80}$

The policy concerning relations with the peasantry was an important aspect of the rebel government in Izhevsk. The fact that a significant part of the peasantry in the region sympathized with the uprising can be considered as

A. Gutman (Gann), "Dva vosstaniia”, Beloe delo. Letopis beloy borbyi, no. 3 (Berlin: Mednyi vsadnik, 1927).

76 Sapozhnikov, Izhevsko-Votkinskoe vosstanie, 57 .

77 TsGA UR. F. R-543. Op. 13. D. 13. L. 70.

78 TsGA UR. F. R-543. Op. 13. D. 13. L. 34, 35.

79 TsGA UR. F. R-543. Op. 13. D. 13. L. 79.

$80 \quad$ TsDNI UR. F. 352. Op. 1. D. 7. Svyazka. 2. L. 2. 
a success for the rebels, which allowed them to significantly increase the potential of their movement. The relationship between the rebel authorities and the inhabitants of the villages around Izhevsk was of course not always ideal. However, the sympathy of a large proportion of the peasantry helped in the formation of the rebels' armed forces and the resolution of the food problem. The new authorities in Izhevsk began to address this latter issue immediately after the uprising. Among the first measures by the new Izhevsk authorities in this regard - that was met with complete support by the peasants - was the permission given for free trade, which had been prohibited under the Bolsheviks. The shops and markets that had been empty under the previous government were revived. New shops opened, and the shoes, handicraft, dishes and metal products for household consumption that had disappeared - or rather, had been hidden until better times - temporarily reappeared. All these steps by the rebel authorities were to be expected: it was not by accident that among the slogans of the uprising, along with political ones there were others such as: "Tea, sugar, white bread and fairs twice a year".81

In order to incentivize the peasants to help with the bread supply for the rebels, the Izhevsk Soviet repeatedly addressed them with special appeals that were widely distributed through the press. ${ }^{82}$ Special district commissioners were selected, who travelled to villages and asked the peasants to part with some grain and flour - as much as they could give. ${ }^{83}$ Bread was bought for money, but often - as even Soviet sources admit - the peasants gave provisions to rebel workers as voluntary donations; "for Christ's sake". ${ }^{84}$ At the same time, it must be remembered that by the autumn of 1918, money was no longer of great value to the peasants, therefore they often regarded the requests of the Izhevsk authorities as requisitions. For that reason, workers often paid for bread with their products; weapons and ammunition. ${ }^{85}$ However, it was also often the case that the peasants did not receive any weapons or money for their bread, but only promissory notes. ${ }^{86}$

Gradually, the food issue in the rebel region became difficult. Freedom of trade, introduced in the early days of the uprising as one of the primary measures to eliminate the Bolshevik heritage, in practice became limited again. Instead, a rationing system emerged. Speculation - the invariable companion

\footnotetext{
81 TsGA UR. F. R-1061. Op. 1. D. 17. L. 20.

82 For example, Izhevskiy zaschitnik, 10 September 1918.

83 Ural i Prikamye, 500.

84 Proletarskaya revolyutsiya, 8-9 (1924).

85 Fedichkin, Izhevskoe vostanie.

86 TsGA UR. F. R-46o. Op. 1. D. 2. L. 156.
} 
of hunger - reappeared, followed by the authorities' attempts to fight it. For example, in September the following order from Commissioner S. Egorov appeared in one of the issues of the Votkinskaya life newspaper:

In view of the fact that lately there has been a large development of extreme speculation in Votkinsk, I consider it necessary to warn those involved that the regime change happened not to indulge predation and plunder of the population by speculators who use everything to fill their pockets. Therefore, the Prikamsky Committee of Members of the Constituent Assembly represented by authorized bodies will mercilessly fight speculation and speculators as enemies of the people, sending them to court where they will be prosecuted to the fullest extent of the law. ${ }^{87}$

Residents in the rebel cities had to suffer labour mobilization as well. For instance, in the descriptions of the battles around Izhevsk one can find references to a powerful line of defensive fortifications built by rebels. Some documents issued by the rebel authorities give a clear description of how they were built. One of them reads:

On 7 September, all citizens aged 16 to 50 without exception must be present at 7 o'clock in the morning with axes, shovels and food for two days on Mikhaylovskaya Square. Those who do not have shovels and an axe will receive them from the district commissioners who will temporarily seize them from the inhabitants of the district. ... Everyone join the trench works immediately! Everyone grab a shovel! A shovel will save Izhevsk: the deeper into the ground, the stronger the defences.

For those who did not see the urgency of the moment, it was explained that any "attempt to shirk from work would be punished with the utmost severity".88

As throughout the rest of the country, the authorities had to deal with a taxation system in Izhevsk that had been completely destroyed. In Soviet Russia, this problem was combatted with the help of trade unions and other bodies of workers' self-government. In Izhevsk, the authorities tried to revive local public organizations. Under the circumstances of an acute shortage of funds, even for maintaining the fighting capacity of the rebel army, appeals to the factory workers' conscience and patriotism became permanent. The tone of

$87 \quad$ Votkinskaya zhizn', 29 September 1918.

88 TsDNI UR. F. 350. Op. 6. D. 50. Svyazka. 2 L. 33. 
these appeals is interesting in itself, since it conveys the peculiarities of those days. For example, in one of the appeals by the Izhevsk authorities, the population was called upon to "immediately donate or give away for a small fee warm clothes that are in excess or are unneeded, such as: fur coats, great-coats, jackets, boots, felt boots, socks, foot cloths, mittens, underwear, soldier's blouses". It was also noted: "Do not hesitate if the donated items are not entirely new. The shortage is severe and the Army will be very grateful for everything". ${ }^{89}$ The authorities in Votkinsk acted in a similar manner: "We appeal to comrades, workers and other citizens: help the city in voluntary sewing of clothing for the People's Army", was stated in one of their communications. "Fathers of families, ask your wives and adult daughters to sew at least one pair of clothing for free. Knowing the responsiveness of the working masses and citizens we have the hope they will treat our request sympathetically and will help in this difficult moment of the renewal of our state".90

The rebel government of Izhevsk, which had tried to find its own "third way" in the early period of the civil war, lasted for only three months. Its main activities, whether in the area of administration, labour policy, the taxation system or other matters, were focused on restoring the trajectory of the country's development; an effort that was started in February and interrupted in October 1917. At the same time, the general conditions of the civil war and other objective and subjective issues undermined the initial democratic impulses of the movement, forcing the course of the Izhevsk authorities in the general direction of that time.

\section{5}

\section{Crisis and Defeat}

The growing difficulties undermined the strength of the rebels' power, and tensions between factions in the rebel leadership escalated. The basis of this conflict was the disagreement between the right-wing socialists in the leadership and the representatives of non-party officers. For instance, according to A. Y. Gutman, the Union of Front-Line Soldiers agreed "quite reluctantly" to the leadership of the "four members of the former Constituent Assembly". It was only the position of other socialist groups supporting the right-wing SR s that forced the war veterans to reconcile themselves with this decision, and even then only temporarily, until the rebels joined the main forces of the

\footnotetext{
89 Izhevskiy zaschitnik, 15 October 1918.

9o Votkinskaya zhizn, 17 September 1918.
} 
White Army. The words Gutman used to describe the formation and activity of Prikomuch very clearly show the true attitude of the "comrades in a common struggle" towards each other. He wrote sarcastically in his memoirs:

The example of the "Komuch" in Samara inspired the Izhevsk Right SR S, and they hastened to declare themselves the Supreme Power under the loud title "Committee of the Constituent Assembly of Prikamye". ... The lure of the Samara Komuch's power was too strong so that several little men accidentally stumbling into public life could not resist the temptation to become the "supreme rulers" of a single uezd of a great state, even for a very short time.... Socialist contagion that did its evils in the capitals and major cities of Russia moved to the Kama. Random, weak and spineless people narrowly driven by party affiliation once again came to power. The sR s came, this time third-rate ones, and the fire of enthusiasm in the struggle for Russia faded.

According to Gutman, the results of "socialist management" were the same: "They chatted in Samara, they chatted in Izhevsk, until the Reds came and crushed everything and everyone". ${ }^{11}$

A strong unitary power remained the ideal of the military officials. They were not satisfied with the "second edition of the Constituent Assembly"; they preferred the "second edition of Kornilovism". Gutman shared his thoughts about this:

If an energetic and firm leader came to power in Izhevsk and managed to subjugate and lead the movement, everyone would have followed him. Everyone would have subordinated themselves to a reasonable will. But unfortunately in Izhevsk, at the time of the uprising, four party leaders valued the dogma much more than the state. Especially when it came to power.

In his opinion, the Izhevsk-Votkinsk uprising could have turned into a "nationwide movement", but this would have needed it to have been led by "people who were not tied tightly to one or another political program but possessed by the idea of saving Russia from Bolshevism and restoring state order". ${ }^{92}$

$91 \quad$ Ural i Prikamye, $377,378,383,39$.
92 Ural i Prikamye, 382. 
The socialists paid back in kind. Taking advantage of their position in the government, they sought to impose in every way their conditions for political coexistence. The officers, even those who had been local factory workers before, were considered by the civil authorities to be "a necessary evil". Only those officers who were members of the socialist parties were credible, one example being G. N. Yuriev, a Social Democrat member of the factory committee, who was for a long time the commander of the Votkinsk rebel group. Gradually the pacifist propaganda of the socialists gave way to "putting an end to the fratricidal war". Some socialists were ready to go even further, preferring the power of the Bolsheviks "over the epaulets and orders of the Tsarist army", which had been "imposed" on the rebels from Siberia. A. I. Gutman describes his private conversation on the eve of the fall of Sarapul with a member of the Prikomuch, the right-wing Social Revolutionary Mikhailov. "We had better reconcile with Bolshevism than with reactionaries", Mikhailov assured him. "And by 'reactionaries' the socialists primarily referred to 'counter-revolutionary officers', as in the times of Kerensky". ${ }^{3}$

The result of the rivalry between the socialists and the officers was a form of dual power, with the relationship between the military and civil administration leading to a direct confrontation. Against this background, a row erupted, which became the latest in the chain of crises of rebel power and the forerunner of its fall. Its beginnings can be traced back to 20 October 1918, when at a joint meeting of senior army officers and the Prikomuch, D. I. Fedichkin proposed starting an emergency evacuation of the wounded, women and children as well as valuable equipment and weapons to the eastern shore of the Kama. He justified his decision by saying that within one week, Izhevsk would not have a single bullet and then they would have to "flee from Izhevsk naked on ice". 94

His plan was not met with understanding. Moreover, Evseev, who by that time had become the civilian leader of the rebel region, called Fedichkin's proposals cowardice. Fedichkin had no choice but to resign, referring to "a poor state of health". The resignation was immediately accepted, and N. Evseev's Order No. 12 of 23 October stated ambiguously that Fedichkin had been dismissed from the post of Commander of the People's Army of Prikamye "because of his poor condition threatening extremely dangerous consequences for the defence". ${ }^{95}$ However, the fear of a military coup was so great that at the end of the meeting the entire board of the civilian government immediately fled to

\footnotetext{
93 Sotsialisticheskiy vestnik, no. 16 (1922): 7.

94 Izhevsko-Votkinskoe vosstanie, 77.

95 TsGA UR. F. R-46o. Op. 1. D. 1. L. 70.
} 
an unknown location. Only after some time did it become known that the "top four" had moved to Votkinsk. As a result, the decision to evacuate people was not made, and major changes took place in the leadership of the People's Army. The socialist Yuryev was appointed to replace Fedichkin and the command of the Izhevsk army units was assigned to captain N. I. Zhuravlev, a man almost unknown to the people of Izhevsk and even to the commanding officers. These changes in all likelihood followed the line of "strengthening" the command of the rebel army by officers close or personally loyal to Evseev. ${ }^{96}$

The turmoil in the leadership of the rebel republic, combined with the increasing anarchy and anti-democratic tendencies in the life of the rebel region, caused growing discontent among the population of Izhevsk, especially among the workers. For instance, in mid-September, the Union of Metalworkers came out to defend those arrested in the days of the August uprising. They formed a special delegation, with the purpose of demanding that the military authorities improved the conditions of prisoners and released the innocent. ${ }^{97}$ Pro-Bolshevik sentiments began to increase among some segments of the factory workers, which was largely due to the vigorous activities of underground groups of Bolsheviks and non-party workers. ${ }^{98}$ Agitators, supplied with a large amount of communist literature and money to attract people to their cause, got into the rebel areas and destroyed the rebels' rear flank from the inside. Their activities in Izhevsk and Votkinsk, and especially in Sarapul, were carried out unpunished, as is clearly noted in the sources from the White Army. Pro-Bolshevik sentiments also spread in the People's Army, strengthening the process of its disintegration. Entire units of the People's Army began to go over to the side of the Reds, a development that had been impossible to imagine prior to that time. ${ }^{99}$

All the moments of crisis noted above, as well as the capital's a priori superior strength over the temporarily seceded provinces, made the defeat of the Izhevsk-Votkinsk uprising inevitable; all the more so, as it became less and less working class in its nature. After taking Sarapul in early October, the units of the Red Army began to prepare for the assault on Izhevsk. The operation of encircling and taking the rebels' main citadel was assigned to a special division of the 2nd Army under the command of V. M. Azin. The order to start the operation was signed on 3 November 1918 by the commander of the Second

96 Ural i Prikamye, 394.

97 Votkinskaya zhizn', 15 September 1918.

98 For more details, see N. P. Dmitriev and K. I. Kulikov, Myatezh v Izhevsko-Votkinskom rayone, $152-154$.

TsGA UR. F. R-35o. Op. 49. D. 6. L. 5 . 
Army, V. I. Shorin, and a member of the Revolutionary Military Council, P. K. Sternberg. ${ }^{100}$ The decisive battle took place on 7 November 1918. In the early morning, an intensive artillery bombardment conducted by government troops began, with the rebels also responding with artillery fire. It was in this battle that, for the first time during the civil war, the Bolsheviks had to face psychological warfare, so vividly recreated in the film Chapaev. As always in moments of great danger, a factory whistle howled over the city and the bells of the Mikhailovsky Cathedral rang, as the most capable troops of the Izhevsk army in their full strength launched their attack under the red and green banner. According to a participant in the conflict, A. P. Kuchkin, this battle could be compared only with those of Chelyabinsk and Perekop in terms of its violence and brutality. ${ }^{101}$ It was not until the evening that the advancing units of the Reds were able to get through the fierce fire and the several lines of wellbuilt fortifications. An armoured train Svobodnaya Rossiya (Free Russia) broke into Izhevsk station, and with its fire created disarray among the defenders, after which infantry and cavalry units entered the city.102

The fights near Izhevsk on 7 and 8 November 1918, together with the actions to normalize the situation in the city, temporarily interrupted the advance of the Second Red Army and allowed the remnants of the rebel army to take steps to organize the evacuation of Votkinsk. The decision to make an emergency evacuation was taken at a special meeting attended by the civilian authorities of the region, the new commander of the Izhevsk-Votkinsk army, Captain Yuriev, Colonel Albokrinov and the commander of the Izhevsk army, Captain Zhuravlev. On 11 November, the Votkinsk plant was abandoned by the rebels and Lieutenant Bolonkin's unit was ordered to cover the planned retreat of the rebels' main forces. On the night of 12 November, the last units of the army crossed the Kama, and the sappers destroyed the pontoon bridge after crossing it. From then on, the fate of Izhevsk rebels was linked to the history of the White movement in the east of the country. ${ }^{103}$

Thus ended the largest anti-Bolshevik uprising of workers in the history of the civil war. It became a serious challenge for the emerging revolutionary state. Izhevsk workers demonstrated the possibility of developing a version of the Russian state during the country's crisis that was neither White nor Red. At the same time, the experience of the right-wing socialist government in

\footnotetext{
$100 \quad$ TsGA UR. F. R-1061. Op. 1. D. 3. L. 67.

101 N. P. Dmitriev and K. I. Kulikov, Myatezh v Izhevsko-Votkinskom rayone, 267-268.

102 Dokumentyi po istorii grazhdanskoy voynyi v SSSR. Vol. 1 (Moscow: Politizdat, 1941), 381-382.

103 TsGA UR. F. R-1061. Op. 1. D. 17. L. 38-39.
} 
Izhevsk showed that democratic power in those circumstances was possible only in the form of a "democratic dictatorship", which in terms of its methods, differed very little from the Bolshevik and military dictatorships. Even if not dead, the political line of the right-wing socialists in Izhevsk had been heavily discredited. Democratic slogans without democratic content could not convince people of their fairness and usefulness when those people were, above all, trying to survive in circumstances of complete collapse and ruin. The civil war relentlessly imposed its own laws, in accordance with which the barricades can only have two sides, and those standing in the middle find themselves in the crossfire.

\section{Bibliography}

Anishev, A. I., Ocherki istorii grazhdanskoy voynyi. 1917-1920 (Leningrad: Voenno-polit. akad. im. t. Tolmacheva RKKA i RKKF, 1925).

Behterev, S. L., Esero-maksimalistskoe dvizhenie v Udmurtii (Izhevsk: Udmurtskii institut istorii, iazyka i literatury UrO RAN, 1997).

"Beloe delo. Letopis beloy borbyi. Berlin", 3, (1927), in Ural i Prikame (Noyabr 1917 - yanvar 1919): Dokumentyi i materialyi, ed. M. S. Bernshtam (Paris: Rosspen, 1982), 385.

"Bezoruzhnoe vooruzhyonnoe vosstanie: proizvodstvo vintovok na izhevskih zavodah vo vremya antibolshevistskogo vyistupleniya", Vestnik Rossiyskogo universiteta druzhbyi narodov. Seriya: Istoriya Rossii, no. 1 (2013): 32-48.

Churakov, Dimitrii, "Der antibolschewistische Arbeiteraufstand in Iževsk. Probleme der Etablierung ziviler Machtorgane August bis November 1918", Arbeit - Bewegung - Geschichte. Zeitschrift für historische Studien 7, no. 2 (2018): 139-160.

Dmitriev, P. N., Soldatskie soyuzyi $v$ Udmurtii. Kanun grazhdanskoy voynyi (formirovanie, sotsialnyiy sostav, otnoshenie s partiyami) (Izhevsk: Muzey - Istoriya i sovremennost, 2000).

Dmitriev, P. N., "Partiyno-politicheskaya sistema Udmurtii v usloviyah stanovleniya sovetskoy gosudarstvennosti (oktyabr 1917 - vesna 1918 gg.), "Rossiyskaya gosudarstvennost: urovni vlasti. Istoricheskaya dinamika. Materialyi Vserossiyskoy nauchnoprakticheskoy konferentsii (Izhevsk: Izdatelskii dom "Udmurdskii universitet", 2001).

Dmitriev, P. N., "Sotsialnyiy oblik rabochih Udmurtii v pervyie desyatiletiya XX v.: sotsialno-byitovyie, proizvodstvennyie, politicheskie aspektyi", in Rabochie Rossii. Istoricheskiy opyit i sovremennoe polozhenie, ed. D. O. Churakov (Moscow: Ėditorial URSs, 2004), 149-164.

Dmitriev, P. N., and K. I. Kulikov, Myatezh v Izhevsko-Votkinskom rayone (Izhevsk: Udmurtiya, 1992).

Dokumentyi po istorii grazhdanskoy voynyi v SSSR. Vol. 1 (Moscow: Politizdat, 1941). 
Efimov, A. G., Izhevtsyi i votkintsyi (borba s bolshevikami 1918-1920 gg.) (Concord, CA: G. N. Blinoff, 1974).

Fedichkin, D. I., "Izhevskoe vostanie", in Pervopohodnik 17 (1974): 62-77.

Gutman (Gann), A., "Dva vosstaniia”, Beloe delo. Letopis beloy borbyi, no. 3 (Berlin: Mednyi vsadnik, 1927).

Istorik i vremya. 20-5o-e gody XX veka: A.M. Pankratova (Moscow, 2000).

Istoriya Vsesoyuznoy Kommunisticheskoy Partii (bolshevikov). Kratkiy kurs. Pod redaktsiey komissii TsK VKP (b) (Moscow: Gos. izd-vo polit. lit-ry, 1938).

Ivanov, A. V., "Sotsialno-politicheskie aspektyi Izhevsko-Votkinskogo vosstaniya 1918 goda v trudah sovetskih istorikov 1920-30-h godov", Vestnik Udmurtskogo universiteta, no. 3 (2012): 47-54.

Izhevsk $v$ ogne grazhdanskoy voynyi, 1917-1918: Iz istorii revoliutsionnogo dvizheniia izhevskikh rabochikh (Izhevsk: Izd. Obl. komissii po provedeniiu desiatoŭ godovshchiny Oktiabr"skoŭ revoliutsii, 1927).

Karevskiy, A. A., "K istorii antibolshevistskogo vosstaniya v Izhevske i Votkinske: vooruzh Yonnyie formirovaniya Prikamya letom - osenyu 1918 g”., in Izhevsko-Votkinskoe vosstanie, ed. A. A. Karevskiy, K. A. Kulagin and D. O. Churakov (Moscow: Posev, 2000), 5-12.

Kazakov, A., I s'ezd i IV konferentsiya professionalnyih soyuzov (Moscow: Profisdat, 1933).

Klimov, I. P., "Deyatelnost pravitelstv 'demokraticheskoy kontrrevolyutsii' Sibiri i Urala na zheleznodorozhnom i vodnom transporte vesnoy-osenyu 1918 goda”, Noveyshaya istoriya Rossii, no. 2 (19), (2017): 53-67.

Korobeynikov, A. V., Volzhskaya flotiliya protiv narodnoy armii (osen' 1918 g.) (Idnakar, Izhevsk, 2012).

Korobeynikov, A. V., Votkinskaya narodnaya armiya $v 1918$ g. (Idnakar, Izhevsk, 2013).

Korobeynikov, A. V., Uchastniki Izhevskogo vosstaniya avgusta - noyabrya 1918 g.: ih sudbyi $i$ spiski po arhivnyim fondam Sovetskoy militsii (Institut kompyuternyih issledovaniy, Izhevsk, 2016).

Kuchkin A. P., "K istorii Izhevskogo vosstaniya", Proletarskaya revolyutsiya, no. 6 (1929): 153-162.

Laveryichev, V. Ya., Monopolisticheskiy kapitalv tekstilnoy promyishlennosti Rossii (19oo1917 gg.) (Moscow: Izd-vo Mosk. un-ta, 1963).

Lekomtsev, V. G.. K istorii Votkinskogo zavoda: Mezhdousobnaya voyna (1918-1919 godyi) (Votkinsk: Russkaia gazeta Udmurtiimurtii, 1998).

Maksimov, V. A., Kulatskaya kontrrevolyutsiya i Izhevskoe vosstanie (Izhevsk: Udpartizdat, 1932).

Melgunov, S. P., Tragediya admirala Kolchaka (Belgrade: Russkaia tipografia, 1930).

Pankratova, A. M., “Tekstilschiki v revolyutsii 1905-1907 gg”, in Rabochiy klass Rossii: Izbrannyie trudyi, ed. A. M. Pankratova (Moscow: Nauka, 1983). 
Posadskiy, A. V., "Izhevskaya brigada v boyu 9 maya 1919 g. glazami belyih i krasnyih", Sibirskiy istoricheskiy almanah. Tom 2. Sibir na perelome epoh. Nachalo HHveka, (Krasnoyarsk: Verso, 2012), 134-137.

Rashin, A. G., Formirovanie promyishlennogo proletariata v Rossii (Moscow: Izd-vo sotsial'no-èkon. lit-ry, 1940).

Renyov, E. G., "Vospominaniya D.I. Fedichkina kak istochnik po izucheniyu Izhevskogo antibolshevistskogo vosstaniya ( 8 avgusta - 8 noyabrya 1918 g.)", Vestnik Udmurtskogo universiteta, no. 3-5 (2011): 158-161.

Ryabuhin, E. A., Vbor'be s kontrrevolyutsiey (Pomosch trudyaschihsya Vyatskoy gubernii Vostochnomu frontu v 1918-1919 gg.) (Kirov: Kirovskoe knizhnoe izdatel'stvo, 1959).

Sapozhnikov, N., "Izhevsko-Votkinskoe vosstanie", Proletarskaya revolyutsiya, no. 8-9 (1924): $5^{-42 .}$

Shvets, I. V., Grazhdanskaya voyna vSibiri i na dalnem Vostoke Rossii: borba respublikanskoy i monarhicheskoy tendentsiy (1917-1922 gg.), (Dissertatija, Chabarovsk, 2007).

Solonitsyin, N., "About the history of the Civil War in the province", in Oktyabr igrazhdanskaya voyna $v$ Vyatskoy gubernii. Sbornik statey i materialov, ed. N. Solonitsyin (Vyatka: Istpart Viatskogo gubkoma VKP(b), 1927).

Solonitsyin, N., ed., Oktyabr i grazhdanskaya voyna v Vyatskoy gubernii (Vyatka: Istpart Viatskogo gubkoma $\operatorname{VkP}(\mathrm{b}), 1927)$.

Solovyov, O. A., "K voprosu o reaktsii Moskovskogo proletariata na fevralskie sobyitiya v Moskve”, 1917 godv istoricheskih sudbah Rossii. Problemyi istorii Fevralskoy revolyutsii (Moscow: Izd-vo Prometey, 1922).

Tsvetkov, V. Zh., ed., Izhevsko-Votkinskoe vosstanie (Moscow: Posev, 200o).

Upovalov, I. G., "Rabochee vosstanie protiv sovetskoy vlasti", in Ural i Prikame (Noyabr 1917 - yanvar 1919). Dokumentyi i materialyi, ed. M. S. Bernshtam (Paris: YMCA Press, 1982), 396-421.

Vereschagin, A. S., "Paradoksyi istoriografii Izhevsko-Votkinskogo vosstaniya", in Akademik P.V. Volobuev. Neopublikovannyie rabotyi. Vospominaniya. Stati, ed. P. V. Volobuev (Moscow: Ross. akad. nauk, 200o).

Zayats, N. A., "O fenomenalnosti Izhevsko-Votkinskogo vosstaniya", Idnakar: metodyi istoriko-kulturnoy rekonstruktsii, no. 1 (2013): 34-48.

Zubarev, S. P., Prikamye v ogne (Izhevsk: Udmurtiia, 1967).

Zubarev, S. P., Za respubliku Sovetov (Izhevsk: Udmurtiia, 1970). 